\title{
How does intellectual capital affect product innovation performance? Evidence from China and India
}

\begin{tabular}{|r|l|}
\hline Journal: & International Journal of Operations and Production Management \\
\hline Manuscript ID & IJOPM-10-2016-0612.R2 \\
\hline Manuscript Type: & Research Paper \\
\hline Keywords: & $\begin{array}{l}\text { intellectual capital, supplier knowledge integration, supply chain } \\
\text { adaptability, product innovation performance, China, India }\end{array}$ \\
\hline \multicolumn{2}{|l}{} \\
\end{tabular}

SCHOLARONE ${ }^{m}$

Manuscripts 


\title{
How does intellectual capital affect product innovation performance? Evidence from China and India
}

\begin{abstract}
Purpose Intellectual capital reflects the sum of existing knowledge a manufacturer is able to leverage and plays a critical role in new product development. This study aims to empirically investigate the mechanisms through which intellectual capital enhances product innovation performance and how economic and institutional environments affect the mechanisms.

Design/methodology/approach Using a knowledge-based view and institutional theory, this study proposes a model on the relationships among intellectual capital, supplier knowledge integration, supply chain adaptability, and product innovation performance. The hypotheses are empirically tested using multiple group structural equation modelling and data collected from 300 Chinese and 200 Indian manufacturers.
\end{abstract}

Findings We find that intellectual capital improves product innovation performance both directly and indirectly through supplier knowledge integration. However, the effects are different in China and India. In particular, the direct effect of intellectual capital on product innovation performance is significantly higher in China than that in India, and intellectual capital improves product innovation performance indirectly through supplier knowledge integration only in India. We also find that supplier knowledge integration improves product innovation performance indirectly through supply chain adaptability in both China and India.

Originality/value Using a moderated mediation model, this study provides insights into the joint effects of intellectual capital, supplier knowledge integration, and supply 
chain adaptability on product innovation performance. The findings enhance current understandings of how supply chain management helps a manufacturer develop new products using existing knowledge and the influences of economic and institutional environments on knowledge and supply chain management.

Keywords intellectual capital, supplier knowledge integration, supply chain adaptability, product innovation performance, China, India

\section{Introduction}

Intellectual capital refers to the knowledge stock embedded in a firm (Nahapiet and Ghoshal, 1998; Subramaniam and Youndt, 2005). Empirical evidence exists that intellectual capital positively affects innovation (Lee et al., 2011; Menor et al., 2007; Subramaniam and Youndt, 2005) and firm performance (Hsu and Wang, 2012; Youndt et al., 2004). Knowledge sourced from suppliers can stimulate creativity and effectively address the interdependence among product, process, and supply chain designs (Cousins et al., 2011; Petersen et al., 2003). Intellectual capital and supplier knowledge integration thus enable a manufacturer to implement and exploit the existing knowledge resided internally and externally in supply networks for product innovation (Youndt et al., 2004; Hult et al., 2006). Although researchers argue that existing knowledge enables a manufacturer to acquire and integrate external knowledge (Cohen and Levinthal, 1990; Szulanski, 1996), the majority of empirical studies take an internal perspective and focus on intellectual capital's direct effects on performance outcomes (e.g., Lee et al., 2011; Subramaniam and Youndt, 2005). By exploring the effect of intellectual capital on supplier knowledge integration and how 
they jointly influence product innovation performance, this study enhances current understandings on how existing knowledge contributes to new product development.

Although researchers argue that knowledge acquired from suppliers enhances new product development (Cousins et al., 2011; Petersen et al., 2003; Un et al., 2010), some empirical studies fail to support a direct and positive relationship between learning from suppliers and product innovation performance (Tavani et al., 2013; Jean et al., 2014). Integrating the knowledge sourced from suppliers, such as technical know-how, changes in factor markets, and suggestions for process improvement, can assist manufacturers in adapting supply chain designs and reconfiguring supply chain resources to deal with unexpected and unpredicted changes and events (Braunscheidel and Suresh, 2009; Lee, 2004). Supply chain adaptability helps manufacturers identify shifts in environments which facilitates the manufacturers to develop new or adjust existing products in a timely and cost-effective manner (Swafford et al., 2006; Blome et al., 2013). Therefore, exploring how supplier knowledge integration and supply chain adaptability jointly influence product innovation performance can provide insights into the mixed findings about the roles of suppliers in new product development (Wang et al., 2011; Gao et al., 2015; Jean et al., 2014) and the mechanisms through which supply chain learning contributes to product innovation performance.

China and India have experienced high-speed economic growth, demonstrated rising levels of innovation performance, and have diversified domestic markets with large low income population (Altenburg et al., 2008; Bruche, 2009; Fan, 2011). Manufacturers in China and India tend to develop new products that are affordable to local customers (Breznitz and Murphree, 2011; Ernst et al., 2015). To benefit from latecomer's advantage, they innovate by adapting and exploiting existing technologies 
and products creatively (Parayil and D’Costa, 2009; Ernst et al., 2015; Radjou et al., 2012). Intellectual capital and supplier knowledge integration enable a manufacturer to apply existing knowledge innovatively which reduces new product development costs and lead-times (Prahalad and Mashelkar, 2010; Radjou et al., 2012). In addition, product innovations may be copied by competitors because of the lack of sufficient market-supporting institutions and may become out of date quickly because of high market uncertainties in China and India (Parayil and D'Costa, 2009; Fan, 2011). The speed for commercialization, which is dependent on a manufacturer's capability to adapt and adjust supply chains quickly, is critical for a manufacturer to profit from product innovation (Blome et al., 2013). Hence, China and India provide interesting contexts to investigate the combined effects of intellectual capital, supplier knowledge integration, and supply chain adaptability on product innovation performance. Moreover, the economic development paths and institutional environments are different in China and India (Parayil and D'Costa, 2009; Saran and Guo, 2005), which may affect a manufacturer's supply chain management and new product development decisions (Marquis and Tilcsik, 2013; Simsek et al., 2015). Conducting the survey in the two countries and comparing the results can not only improve the generalizability of the findings but also provide insights into the impacts of economic and institutional environments on how intellectual capital affects product innovation performance. By combing a knowledge-based view (KBV) of the firm and institutional theory, this study links a manufacturer's existing knowledge with supply chain management and external environments. The findings enhance current understandings on the complex relationships among intellectual capital, supply chain learning and adaptability, product innovation, and environmental conditions, and how to develop new products by exploiting existing knowledge and collaborating with suppliers. 
The objective of this study is to empirically investigate how intellectual capital influences product innovation performance. This study addresses two research questions. First, how do intellectual capital, supplier knowledge integration, and supply chain adaptability jointly influence product innovation performance? Second, how do economic and institutional environments affect such influences?

\section{Theoretical Background and Research Hypotheses}

\subsection{Knowledge-Based View}

KBV considers knowledge as an important strategic resource of a manufacturer (Kogut and Zander, 1992; Grant, 1996; Szulanski, 2000). Scholars further argue that a manufacturer's knowledge comes not only from within its boundary but also from a wider network of supply chain relationships (Hult et al., 2006; Zhang et al., 2015). This study focuses on intellectual capital and supplier knowledge integration because they represent the internal and external sources of knowledge a manufacturer can leverage.

Intellectual capital reflects the intangible assets held by individuals, stored within organizational processes and structures, and resided in social relationships (Youndt et al., 2004). Intellectual capital can be conceptualized as three complementary dimensions: human (i.e., employees' knowledge and skills), structural (i.e., operating procedures and systems), and social capital (i.e., social relationships and interactions among employees) (Lee et al., 2011; Youndt et al., 2004). Empirical evidence exists that the three components are complementary and their interactions are positively associated with performance outcomes (Subramaniam and Youndt, 2005; Youndt et al., 2004). Hence, we conceptualize intellectual capital as a second-order construct to capture the combined effects of human, structural, and social capital (Hsu and 
Sabherwal, 2012; Menor et al., 2007). Supplier knowledge integration refers to a manufacturer's ability to acquire knowledge from suppliers and apply the knowledge into operations (Hult et al., 2004; Song et al., 2005). The information and know-how obtained from suppliers can enlarge a manufacturer's knowledge base and enable the manufacturer to develop new applications for existing knowledge and to create new product designs (Zhang et al., 2015).

$\mathrm{KBV}$ argues that manufacturers can develop capabilities and gain superior performance by acquiring and implementing knowledge (Grant, 1996; Hult et al., 2004). This study focuses on supply chain adaptability and product innovation performance. Supply chain adaptability refers to a manufacturer's ability to quickly and efficiently adapt product and supply chain designs in response to market changes (Engelhardt-Nowitzki, 2012; Swafford et al., 2006). An adaptable supply chain enables manufacturers to gain competitive advantages by quickly adapting existing products and technologies (e.g., implementing engineering changes), identifying new resources (e.g., acquiring raw materials for new products), and solving problems (e.g., in commercialisation and launch) (Blome et al., 2013; Lee, 2004). Product innovation performance refers to how well a manufacturer develops new products (Chandy and Tellis, 1998). Customer preferences change very quickly in China and India due to globalisation and fast economic growth (Fan, 2011). Manufacturers need to develop more new products with fewer resources for more people, and make adaptations, refinements, and improvements to existing products quickly (Prahalad and Mashelkar, 2010; Breznitz and Murphree, 2011; Radjou et al., 2012). Hence, the number of new products developed and the speed and frequency of new product introduction are critical for the success of product innovation (Parayil and D'Costa, 2009). 
KBV also indicates that a manufacturer's capability to integrate and utilise external knowledge is largely influenced by its prior knowledge base (Cohen and Levinthal, 1990; Szulanski, 1996). Hence, we argue that intellectual capital helps a manufacturer integrate knowledge from suppliers which then improves product innovation performance (Cousins et al., 2011; Szulanski, 2000). In this way, this study proposes that intellectual capital can improve product innovation performance both directly and indirectly through supplier knowledge integration. In addition, a manufacturer can acquire different kinds of knowledge from suppliers, such as inventory levels, production planning, new applications of raw materials or components, process improvement suggestions, and new product ideas (Kogut and Zander, 1992; Zhang et al., 2015). Some of the knowledge can be applied in new product development and hence supplier knowledge integration can improve product innovation performance directly. Others allows the manufacturer to adapt supply chain processes according to new product designs (Braunscheidel and Suresh, 2009; Atuahene-Gima, 2005). Therefore, we argue that supplier knowledge integration also improves product innovation performance indirectly through supply chain adaptability.

\subsection{Institutional Theory}

Institutional theory argues that manufacturers' practices and strategies are substantially influenced and shaped by the broader social institutional settings in which they operate (DiMaggio and Powell, 1983; Marquis and Tilcsik, 2013; Peng et al., 2008). Institutions set legitimate requirements on manufacturers which lead to isomorphism among them (DiMaggio and Powell, 1983). Manufacturers's strategic choices are made within environmental conditions and constraints (Peng et al., 2008). Hence, the institutional theory indicates that manufacturers' behaviour and decisions, including product innovation and supply chain management practices, are influenced 
by the prominent features of a country's economic and institutional environments (Marquis and Tilcsik, 2013; Simsek et al., 2015). Scholars further argue that the evolution of a country's economic and institutional environments affects manufacturers' operations (Boeker, 1989). Manufacturers preserve previously adopted structures and capabilities which persist in the long run due to inertia or institutionalisation (Marquis and Tilcsik, 2013; Simsek et al., 2015). They tend to follow the strategies or practices that are rewarded or encouraged by environmental conditions to ensure survival and growth (Boeker, 1989; Peng et al., 2008). China and India have different political and legal institutions and patterns of economic development (Parayil and D'Costa, 2009; Saran and Guo, 2005). Therefore, we propose that the mechanisms through which intellectual capital influences product innovation performance are different in China and India. The conceptual model and all proposed hypotheses are provided in Figure 1.

Figure 1 about here

\subsection{Research Hypotheses}

Intellectual capital enables manufacturers to find new applications for existing technologies and to synthesise existing capabilities in a fresh way, both of which are critical for designing affordable products (Ernst et al., 2015; Radjou et al., 2012). In particular, employees' knowledge and skills allow manufacturers to quickly reverse engineer and adapt existing products and technologies based on local customers' preferences (Prahalad and Mashelkar, 2010). Operating procedures and systems can keep the knowledge created by employees and hence manufacturers can use the knowledge even when the employees leave the manufacturers (Lee et al., 2011). They can also standardise the development of new products, and reduce the variety in and 
improve the efficiency of product innovation (Ernst et al., 2015). Technical manuals and databases help employees reuse existing modules and components in product innovation to satisfy price-sensitive customers (Radjou et al., 2012). Social relationships facilitate collaboration and cooperation among employees (Nahapiet and Ghoshal, 1998). They are critical for the employees to access each other's private and personal knowledge (Szulanski, 1996). Interactions between employees also allow manufacturers to implement cross-functional teams on new product development, solve conflict among different departments, and make joint decisions on the price, quality, and functionality of new products which are important for adapting products quickly (Szulanski, 2000; Zhang et al., 2014). Hence, manufacturers with higher levels of intellectual capital are more capable of responding to varying and unpredictable market environments by introducing new products quickly and frequently (Atuahene-Gima, 2005). Therefore, we propose the following hypothesis.

\section{H1: Intellectual capital directly improves product innovation performance.}

Intellectual capital retains a manufacturer's past experiences on supplier collaboration within employees' knowledge and organisational procedures (Lee et al., 2011). Manufacturers thus can rely on intellectual capital to identify suppliers' valuable knowledge and integrate such knowledge (Szulanski, 1996; Menor et al., 2007). Product innovation requires manufacturers to develop fresh insights into supply chain operations, technology trends, and local markets (Radjou et al., 2012). Such knowledge can be sourced from suppliers (Gao et al., 2015; Zhang et al., 2015). For example, suppliers can provide knowledge on new applications of existing materials, information about the components and modules used in competitors' products, and new product ideas (Zhang et al., 2015; Zhang et al., 2014). The knowledge enables a manufacturer to imitate competitors' products and to adapt 
existing products by designing new components or reconfiguring modules innovatively, thereby increasing the speed and frequency of new product introduction (Chandy and Tellis, 1998; Jean et al., 2014). In addition, supplier knowledge integration supplements internal research and development (R\&D) efforts and enables a manufacturer to exploit suppliers' knowledge for new product development (Cousins et al., 2011). The manufacturer can thus develop more products with fewer R\&D investments (Radjou et al., 2012). Integrating knowledge acquired from suppliers also enhances a manufacturer's ability to generate new ideas on how to extend functionality or improve specifications when customising and localising products, and assists the manufacturer in developing products concurrently with suppliers (Un et al., 2010; Wang et al., 2011). Moreover, incorporating suppliers' new ideas and designs when adapting products helps a manufacturer enhance product quality and manufacturability and make better decisions on product features (Jean et al., 2014; Tavani et al., 2013), improving product innovation performance. Therefore, we propose the following hypothesis.

H2: Intellectual capital improves product innovation performance indirectly through supplier knowledge integration.

Knowledge acquired from suppliers, such as inventory levels and production planning, can improve a manufacturer's procurement and manufacturing processes (Tavani et al., 2013), and help the manufacturer reduce delivery lead-times and improve supply chain responsiveness and flexibility (Un et al., 2010). In addition, supplier knowledge integration allows manufacturers to capture the latest information and to develop a better understanding about their supply chains (Nahapiet and Ghoshal, 1998; Petersen et al., 2003) which help the manufacturers rapidly adapt to changing environments (Lee, 2004). Hence, knowledge acquired from suppliers can 
be implemented to adjust and adapt supply chain processes with reduced reaction times, enhancing supply chain adaptability (Braunscheidel and Suresh, 2009; Tavani et al., 2013).

An adaptive supply chain is able to leverage supply chain resources to adjust operations swiftly and nimbly and to profit from rapidly changing environments (Blome et al., 2013). This capability enables manufacturers to innovate by localising and customising existing products and technologies (Ernst et al., 2015). Supply chain adaptability also enables a manufacturer to adjust supply chain processes quickly according to new product designs which can speed up the commercialisation of product innovations (Braunscheidel and Suresh, 2009; Engelhardt-Nowitzki, 2012). An adaptable supply chain can deal with the negative effects of late engineering or specification changes by enabling a manufacturer to launch products into markets as basic platforms and then to improve designs based on user feedback (Swafford et al., 2006). Hence, supply chain adaptability enables a manufacturer to introduce more new products quickly. Therefore, we propose the following hypothesis.

H3: Supplier knowledge integration improves product innovation performance indirectly through supply chain adaptability.

China and India liberalised their markets in 1978 and 1991 respectively. Since then, both countries have experienced rapid economic growth (Bruche, 2009). However, they have followed different growth paths (Fan, 2011; Parayil and D'Costa, 2009). Compared to India, China reformed its economic systems much earlier. China also developed at a faster pace and received larger inflows of foreign direct investment (Table 1). In addition, exports of goods and services and high-technology exports play more important roles in Chinese economic development (Table 1). The Chinese government has practiced the "swap market for technology" strategy that 
encouraged Chinese manufacturers to form joint-ventures with Western firms seeking access to China's large and growing markets, enabling Chinese manufacturers to learn advanced technologies, production techniques, and management skills (Altenburg et al., 2008; Breznitz and Murphree, 2011). As an important part of global production network and with the help of intensive capital investment, Chinese manufacturers can and must build extensive intellectual capital to catch up with domestic and foreign customers' changing and novel demands. Moreover, the Chinese government has provided supportive policies to motivate Chinese manufacturers to implement the "self-dependent innovation" strategy that emphasised endogenous innovation using internal resources and capabilities (Parayil and D'Costa, 2009). Manufacturers that answer such institutional arrangements are rewarded by the government. Thus, Chinese manufacturers are encouraged by the environment to rely on internal knowledge and resources, such as intellectual capital, to develop new products. In contrast, India has followed an import substitution policy and relied on domestic resource mobilisation with much lower foreign capital participation (Fan, 2011). Hence, Indian manufacturers may accumulate fewer technological capabilities and successful new product development experiences by exporting and supplying Western customers and thus may depend less on intellectual capital for product innovation compared to Chinese manufacturers. We argue that the differences in economic growth paths and institutional environments in China and India moderate the direct effect of intellectual capital on product innovation performance.

Table 1 about here

Although both China and India are experiencing transition to market economies (Altenburg et al., 2008; Fan, 2011), they have different legal and political 
environments (Rajagopalan and Zhang, 2008; Saran and Guo, 2005). India maintains a legal system inherited from the colonial era. Various legislations first introduced by the British are still in effect and laws also incorporate important US court decisions. For example, the Indian Contract Act was passed by British India and is based on the principles of British Common Law. India also adopts the Westminster style of democracy with a multi-party system. The legislature, the executive, and the judiciary are independent of each other. Laws in China are influenced by traditional Chinese approaches and philosophies (Saran and Guo, 2005). Moreover, the Communist Party of China is the sole governing party and has ultimate authority throughout the economic system. Officials can undermine the rule of law and the execution of law is largely subject to local authorities' discretion (Zhou and Poppo, 2010). Inadequacy and enforcement inefficiency characterise China's legal environment and manufacturers may suffer from unlawful or unfair competitive behaviour, such as contract violation, copyright piracy, and counterfeiting, when involving suppliers directly in product innovation (Wang et al., 2011). Hence, legal institutions cannot provide sufficient protection for Chinese manufacturers' business interests during collaborative innovation with suppliers. In comparison to China, India's legal framework is relatively more developed and more effective. Indian manufacturers can follow formal legal processes and depend on contracts for settling disputes, resolving conflict, and gaining protection when developing new products collaboratively with suppliers. We argue that the differences in institutional environments in China and India moderate the roles played by suppliers in product innovation and hence the indirect effect of intellectual capital on product innovation performance. Therefore, we propose the following hypothesis. 
H4: The mechanisms through which intellectual capital influences product innovation performance are different in China and India.

\section{Methodology}

\subsection{Questionnaire Design}

Based on the relevant literature, a survey instrument was designed to measure a manufacturer's intellectual capital, supplier knowledge integration, supply chain adaptability, and product innovation performance. In addition, the questionnaire included the demographic profile of the manufacturer (e.g., industry, age, size, R\&D investment, and training budget). A multiple-item, 7-point Likert-type scale $(1=$ "strongly disagree"; 7 = "strongly agree") was employed for all constructs. The questionnaire was developed in English. We organised a panel of academics to review the English version of the questionnaire and to translate it into Chinese. The Chinese version was then translated back into English and checked against the original to verify the reliability of the survey instrument. The English and Chinese versions were used in India and China for data collection respectively. The scales, which consist of 21 measurement items, are listed in the appendix.

Intellectual capital was measured by three first-order constructs adapted from Subramaniam and Youndt (2005). In particular, three items regarding employees' skills and expertise were used to measure human capital; structural capital was operationalized as a firm's manuals, procedures, rules, databases, and systems using three items; and social capital was measured by the interactions and relationships among employees using another three items (Subramaniam and Youndt, 2005). Supplier knowledge integration was operationalized as acquiring and applying knowledge from suppliers using four items that were adapted from Hult et al. (2004) 
and Song et al. (2005). Supply chain adaptability was gauged by four items examining the capabilities for problem solving and changing product and supply chain designs quickly. They were adapted from Swafford et al. (2006) and Blome et al. (2013). Product innovation performance was measured by four items gauging the number, speed, and frequency of new product introduction (Atuahene-Gima, 2005; Chandy and Tellis, 1998).

We included R\&D investment as a control variable in the analysis as manufacturers who have invested more in $\mathrm{R} \& \mathrm{D}$ tend to have better product innovation performance (Un et al., 2010). It was measured by the percentage of annual sales invested in R\&D. We also controlled for firm size and age which were measured by the number of employees and years of operation respectively. Larger manufacturers may have higher capabilities and more resources for product innovation, and elder manufacturers may have accumulated more expertise and experiences for new product development (Un et al., 2010). Moreover, we controlled for training budget as task-related training can upgrade employees' skills which may improve product innovation performance. This was measured by the percentage of annual sales spent on training.

\subsection{Data Collection}

We interviewed 15 manufacturers in China to pilot test the questionnaire. We then decided to use one key informant per manufacturer who is knowledgeable about supply chain management and product innovation and is familiar with knowledge management practices. Such key informants can be general managers or directors, senior R\&D managers, operations/manufacturing managers, and supply chain managers. 
In China, manufacturers were selected from three special economic zones (i.e., Pearl River Delta, Yangtze River Delta, and Circum-Bohai Economic Zone). We randomly selected 2379 manufacturers from the target industries (Table 2) in the three regions using the directory provided by the National Bureau of Statistics of the People's Republic of China. A professional market research firm was hired to conduct the data collection. The firm contacted the target manufacturers by telephone to identify and verify the informant who was able to answer the survey questions and to solicit his/her participation in the survey. Of the selected sample, 2061 could not be contacted due to incorrect contact information or they did not wish to participate in the survey. The market research firm sent representatives to visit the respondents from the remaining 318 manufacturers on site. Finally, 300 completed questionnaires were returned for a response rate of $12.6 \%(300 / 2379)$.

In India, manufacturers were randomly selected from important industrial cities, including Delhi, Mumbai, Bangalore, Chennai, Kolkata, Chandigarh, and Ahmadabad and from the same industries as those in China. The manufacturers were selected from the IndiaMART business directory, the most comprehensive business directory of companies in India. A professional market research firm was also hired for data collection. Using a similar approach, the firm contacted target manufacturers by telephone to identify and verify the appropriate informants, resulting in a sample of 550 manufacturers who agreed to participate in this study. The firm sent representatives to collect data through face-to-face interviews with the appropriate respondents and finally collected 200 valid responses. The response rate is $36.4 \%$ (200/550). The demographic statistics of the sample manufacturers are shown in Table 2.

Table 2 about here 
We conducted four statistical tests using SPSS 21.0 and AMOS 21.0 to assess common method bias. First, we performed Harman's single factor test using unrotated exploratory factor analysis (Podsakoff et al., 2003). The largest percentage of variances explained is $26.1 \%$ in the Indian sample and $19.3 \%$ in the Chinese sample, indicating that the magnitude of common method bias is not significant. Second, we constructed a confirmatory factor analysis (CFA) model in which the common method was treated as a single factor loading on all items (Podsakoff et al., 2003). The fit indices are $\chi^{2}(189)=1514.58, \chi^{2} / \mathrm{df}=8.01$, Comparative Fit Index $(\mathrm{CFI})=0.56$, Tucker Lewis Index $(\mathrm{TLI})=0.52$, Root Mean Square Error of Approximation $($ RMSEA $)=0.15$ in the Chinese sample, and $\chi^{2}(189)=702.71, \chi^{2} / \mathrm{df}=3.72, \mathrm{CFI}=0.74$, $\mathrm{TLI}=0.71, \mathrm{RMSEA}=0.12$ in the Indian sample, which are unacceptable (Hu and Bentler, 1999). Third, we constructed a conventional CFA model with each construct loading on its own items. Next, we added a common factor loading on all items to this CFA model. The purpose of this method is to estimate the amount of variance from each item that can be attributed to the common method (Podsakoff et al., 2003). The results show that the average variance explained by the common method is only $3.3 \%$ in the Chinese sample and $9.6 \%$ in the Indian sample, indicating that the common method bias is minimal. Finally, we introduced a marker variable, environmental uncertainty (EU), to gauge and partial out the effect of common method (Lindell and Whitney, 2001). The smallest positive correlation between EU and other constructs is 0.02 (insignificant) and 0.12 (insignificant) in the Chinese and Indian samples respectively. Using Lindell and Whitney's (2001) estimation method, we calculated the corrected correlations and t values for all pairs of correlations between constructs in this study. The results indicate that all corrected correlations do not change much 
and remain significant in both Chinese and Indian samples. Therefore, we drew the conclusion that common method bias is not a serious problem in this study.

\subsection{Psychometric Test}

We employed Cronbach's alpha and composite reliability for assessing construct reliability. The Cronbach's alpha values range from 0.72 to 0.87 and the composite reliabilities range from 0.84 to 0.91 (appendix) which are all above the recommended threshold value of 0.70 , suggesting that all constructs are reliable in both Chinese and Indian samples.

We used average variance extracted (AVE) and CFA to assess the convergent and discriminant validity. All of the AVE values range from 0.63 to 0.72 , which are above the recommended value of 0.50 (appendix), thereby demonstrating adequate convergent validity in both samples (Fornell and Larcker, 1981). We built a secondorder CFA model to further assess the convergent validity. In the model, the items for intellectual capital were linked first to the three first-order constructs (i.e., social, structural, and human capital), which then loaded onto the second-order construct, and the items for supplier knowledge integration, supply chain adaptability, and product innovation performance were directly linked to corresponding constructs. The covariance among the constructs was freely estimated. The model fit indices are $\chi^{2}(180)=318.49, \chi^{2} / \mathrm{df}=1.86, \mathrm{CFI}=0.95, \mathrm{TLI}=0.95, \mathrm{RMSEA}=0.05$ in the Chinese sample, and $\chi^{2}(180)=310.99, \chi^{2} / \mathrm{df}=1.73, \mathrm{CFI}=0.93, \mathrm{TLI}=0.92, \mathrm{RMSEA}=0.06$ in the Indian sample, which are better than the threshold values recommended by $\mathrm{Hu}$ and Bentler (1999). In addition, all factor loadings are greater than 0.50 (appendix), with all $\mathrm{t}$ values greater than 2.0. The results indicate that convergent validity is ensured in both Chinese and Indian samples. 
Discriminant validity was assessed by comparing the square roots of the AVE of each construct with the correlations between the focal and other constructs. A square root higher than the correlation with other constructs suggests discriminant validity (Fornell and Larcker, 1981). Table 3 shows the means and standard deviations of the constructs and their correlations. Comparisons of the correlations and square roots of the AVEs on the diagonal indicate adequate discriminant validity for all constructs in both Chinese and Indian samples. We also assessed discriminant validity by building a constrained CFA model for every possible pair of latent constructs in which the correlations between the paired constructs were fixed to 1.0. This was compared with the original unconstrained model, in which the correlations among constructs were freely estimated. A significant difference in the chi-square statistics between the constrained and unconstrained models indicates high discriminant validity (Fornell and Larcker, 1981). This method was used in both Chinese and Indian samples, and all differences are significant at the 0.001 level, indicating that discriminant validity is ensured.

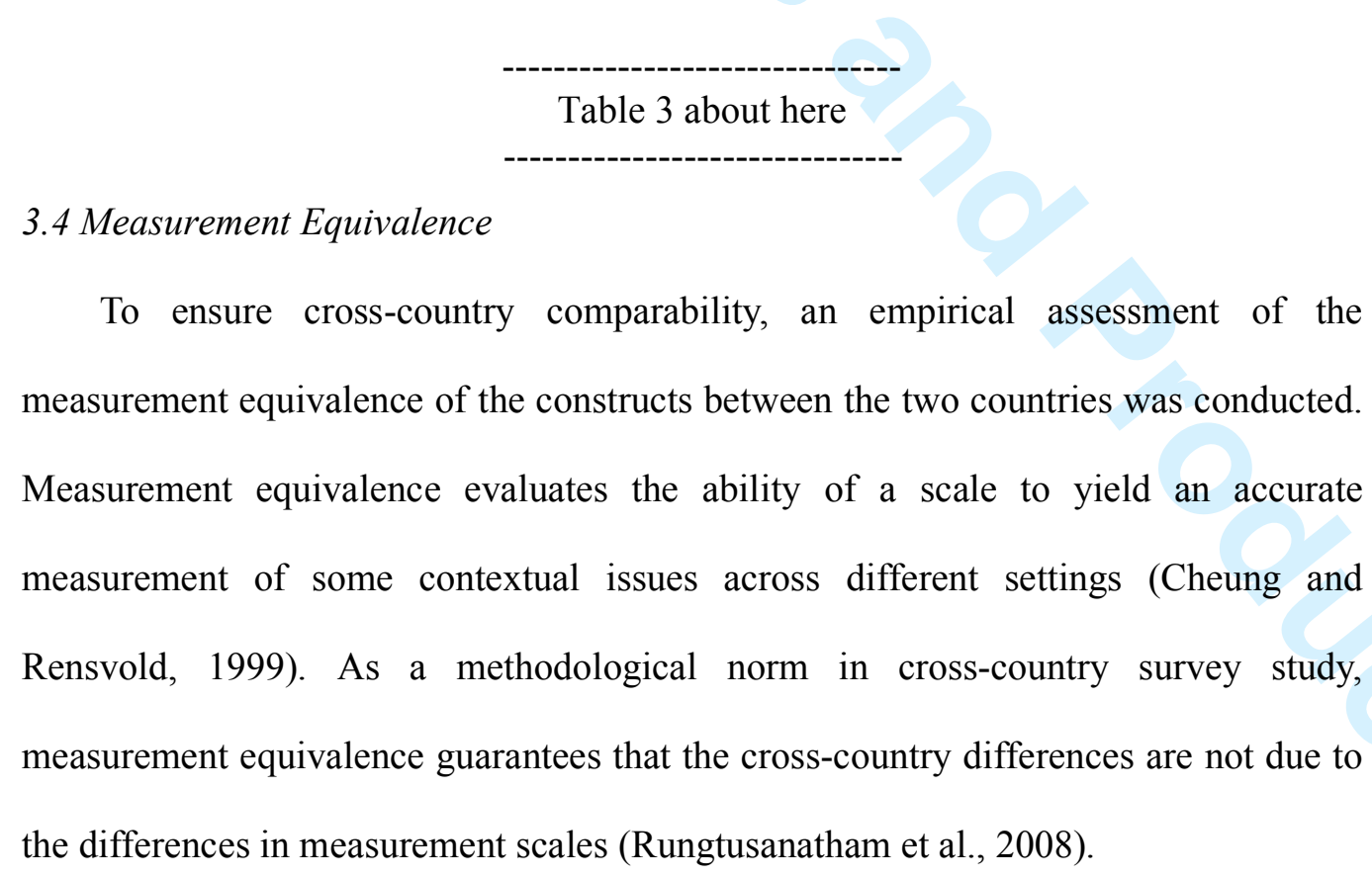
measurement equivalence of the constructs between the two countries was conducted. Measurement equivalence evaluates the ability of a scale to yield an accurate measurement of some contextual issues across different settings (Cheung and Rensvold, 1999). As a methodological norm in cross-country survey study, measurement equivalence guarantees that the cross-country differences are not due to the differences in measurement scales (Rungtusanatham et al., 2008). 
The measurement equivalence between Chinese and Indian samples was assessed with the method recommended by Rungtusanatham et al. (2008) using multiple-group CFA. First, a stacked model was built to assess configural equivalence which refers to the extent to which Chinese and Indian samples share the same factor structure. The configural model fits well between the two samples $\left(\chi^{2}(360)=629.59, \chi^{2} / \mathrm{df}=1.75\right.$, $\mathrm{CFI}=0.95, \mathrm{TLI}=0.95, \mathrm{RMSEA}=0.039)$ and all factor loadings and variances are statistically significant. These results establish configural equivalence between the two samples (Rungtusanatham et al., 2008). Second, metric equivalence was assessed with a nested CFA model which determines the extent to which individual factor loadings are identical across the two samples. In this model, the factor loadings were constrained to be equal across the two samples and other parameters were freely estimated. The insignificant change $\left(\Delta \chi^{2}(17)=24.74, p>0.1\right)$ between the unconstrained and the constrained models shows the evidence of the metric equivalence. Third, starting with the second model, another nested model was built to assess the measurement error variance invariance (MEVI) which refers to the extent to which measurement error variances for individual items are identical across the two samples. In this model, the measurement error variances were further constrained to be equal across the two samples and other parameters were freely estimated. The significant change $\left(\Delta \chi^{2}(51)=329.16, p<0.01\right)$ shows that the full MEVI cannot be established. Thus, a series of CFA models were built to assess partial MEVI. The results show that partial MEVI can be established across the two samples. As suggested by Rungtusanatham et al. (2008), partial MEVI is enough for further comparative analyses across two countries.

\section{Analysis and Results}


The hypotheses are tested using structural equation modelling (SEM) with the maximum likelihood estimation method. The proposed model for each country (i.e., China and India) is stacked and tested using AMOS 21.0. The results are presented in Figure 2. The model fit indices are $\chi^{2}(518)=950.54, \chi^{2} / \mathrm{df}=1.84, \mathrm{CFI}=0.92, \mathrm{TLI}=0.91$, RMSEA=0.041, which are acceptable (Hu and Bentler, 1999). We find that in China, intellectual capital significantly enhances supplier knowledge integration $(b=0.57$, $\mathrm{p}<0.01)$ and product innovation performance $(b=0.39, \mathrm{p}<0.01)$. Supplier knowledge integration increases supply chain adaptability $(b=0.56, \mathrm{p}<0.01)$ which positively influences product innovation performance $(b=0.29, \mathrm{p}<0.01)$. However, the direct effect of supplier knowledge integration on product innovation performance is not significant. In India, product innovation performance is positively influenced by intellectual capital $(b=0.32, \mathbf{p}<0.01)$, supplier knowledge integration $(b=0.25, \mathbf{p}<0.05)$, and supply chain adaptability $(b=0.36, \mathrm{p}<0.01)$. Intellectual capital also increases supplier knowledge integration $(b=0.71, \mathrm{p}<0.01)$ and supplier knowledge integration enhances supply chain adaptability $(b=0.53, \mathrm{p}<0.01)$. The results show that the direct effect of intellectual capital on product innovation performance is significant and positive in both countries. Thus, H1 is supported. Moreover, the effects of the four control variables on product innovation performance are not significant in both countries.

Figure 2 about here

As recommended by Malhotra et al. (2014), bootstrapping method is used to test the mediation effects in both Chinese and Indian samples. Accordingly, bias-corrected bootstrapping with 5000 samples is conducted in each sample. The indirect effect of intellectual capital on product innovation performance through supplier knowledge integration is insignificant in China but significant in India $(b=0.32, \mathrm{p}<0.05)$. 
Therefore, H2 is partially supported. The indirect effect of supplier knowledge integration on product innovation performance through supply chain adaptability is significant in both China $(b=0.16, \mathrm{p}<0.01)$ and India $(b=0.19, \mathrm{p}<0.01)$. Therefore, H3 is supported.

A multiple group (i.e., China vs India) SEM analysis is further conducted to compare the relationships among intellectual capital, supplier knowledge integration, supply chain capability, and product innovation performance. As the control variables do not significantly influence the dependent variable (i.e., product innovation performance), we exclude them in the cross-country comparison analysis to keep the model parsimonious. The bias-corrected bootstrapping is also conducted to compare the indirect effects in the two countries (Malhotra et al., 2014). Table 4 summarizes the results of cross-country comparisons for the path coefficients.

Table 4 about here

The results show that the direct effect of intellectual capital on product innovation performance in China is significantly higher than that in India $\left(\Delta \chi^{2}=3.18\right)$. In addition, the path coefficient from supplier knowledge integration to product innovation performance is positive and significant in India but insignificant in China ( $\Delta \chi^{2}=10.73$ ), and the indirect effect of intellectual capital on product innovation performance through supplier knowledge integration in China is significantly lower than that in India $(\Delta b=0.30, \mathrm{p}<0.01)$. Thus, the mechanisms through which intellectual capital influences product innovation performance are different in China and India. Therefore, H4 is supported. The path coefficients from intellectual capital to supplier knowledge integration, from supplier knowledge integration to supply chain adaptability, and from supply chain adaptability to product innovation 
performance are not significantly different between the two countries. The indirect effect of supplier knowledge integration on product innovation performance through supply chain adaptability in China is also not significantly different from that in India.

\section{Discussion and Conclusions}

\subsection{The Direct Effect of Intellectual Capital on Product Innovation Performance}

This study finds that intellectual capital directly improves product innovation performance. The result is consistent with existing empirical evidence (Subramaniam and Youndt, 2005; Hsu and Sabherwal, 2012; Lee et al., 2011) and the argument that a firm's knowledge base helps the firm innovate (Cohen and Levinthal, 1990; Szulanski, 1996). Therefore, using existing knowledge creatively is critical for manufacturers who do not focus on developing state-of-the-art technological advances in a product category to innovate. We also find that this effect is moderated by a country's environmental conditions. Manufacturers in the countries that have introduced more policies driving endogenous innovation and accumulated more technological and managerial knowledge during economic development rely more on intellectual capital for developing new products.

\subsection{The Indirect Effect of Intellectual Capital on Product Innovation Performance through Supplier Knowledge Integration}

We find that the impact of intellectual capital on product innovation performance is partially mediated by supplier knowledge integration and the mediation effect is moderated by a country's institutional environment. The results are consistent with Hsu and Sabherwal (2012)'s finding that knowledge management mediates the effect of intellectual capital on innovation and corroborate the existing literature on the influences of institutional environment on supply chain collaboration (Wang et al., 
2011; Jean et al., 2014; Zhou and Poppo, 2010). It is difficult for manufacturers to perform adequate due diligence and to manage supply chain collaboration using formal control mechanisms in the countries that lack reliable public information channels, professionals (e.g., actuaries, accountants, and surveyors), and strong corporate governance (Rajagopalan and Zhang, 2008; Zhou and Poppo, 2010). Therefore, manufacturers in such countries do not directly use knowledge acquired from suppliers for innovation because this means the manufacturers must share knowhow with suppliers which might be leaked to competitors as legal and political institutions may fail to protect their intellectual property rights (Rajagopalan and Zhang, 2008; Zhou and Poppo, 2010). In the countries that have well-developed contract and intellectual property laws, manufacturers are able to apply knowledge obtained from suppliers directly in innovation because their business interests can be protected by legal means. We also find that intellectual capital positively affects supplier knowledge integration, which is consistent with the argument that prior knowledge base helps a manufacturer acquire and integrate knowledge from suppliers (Tavani et al., 2013; Zhang et al., 2015).

\subsection{The Indirect Effect of Supplier Knowledge Integration on Product Innovation} Performance through Supply Chain Adaptability

The result reveals that supply chain adaptability mediates supplier knowledge integration's effect on product innovation performance. This is consistent with the existing empirical evidence that knowledge acquired from suppliers is positively associated with new product development (Petersen et al., 2003; Cousins et al., 2011; Tavani et al., 2013) and improves a manufacturer's supply chain capabilities (Hult et al., 2004; Hult et al., 2006). Supplier knowledge integration enables manufacturers to acquire knowledge related to supply chain processes. The knowledge can help the 
manufacturers adapt and improve supply chains to commercialise new product designs quickly and efficiently which is critical for the manufacturers to enhance product innovation performance.

\subsection{Theoretical Contributions}

This study contributes to operations management literature in three ways. First, this study provides empirical evidence that the impact of intellectual capital on production innovation performance is partially mediated by supplier knowledge integration. The finding clarifies the mechanisms through which intellectual capital enhances product innovation performance and the joint effects of internal and supplier knowledge on new product development. The majority of current studies focus on the relationships between intellectual capital and a firm's internal capabilities and operations (e.g., Hsu and Wang, 2012; Menor et al., 2007; Subramaniam and Youndt, 2005). This study links intellectual capital with supply chain learning and reveals that supplier knowledge integration may carry intellectual capital's effects on product innovation performance. Therefore, we suggest scholars consider intellectual capital in a supply chain context to fully capture its effects. In addition, we find that the direct effect of intellectual capital and the mediation effect of supplier knowledge integration are moderated by the environmental conditions of a country. Hence, we suggest scholars adopt a contingent view and consider the influences of political and legal institutions when investigating the effects of intellectual capital (Youndt et al., 2004; Zhou and Poppo, 2010).

Second, this study finds that supply chain adaptability mediates the impact of supplier knowledge integration on product innovation performance. The result shows that knowledge acquired from suppliers enhances product innovation performance only indirectly through supply chain adaptability in China which provides a possible 
explanation for the mixed findings on the roles played by suppliers in product innovation (Gao et al., 2015; Jean et al., 2014). The findings also indicate that a manufacturer can acquire different kinds of knowledge from suppliers which enhance product innovation performance either directly or indirectly by improving supply chain processes and capabilities, providing insights into how suppliers contribute to new product development. Therefore, to fully reap the benefits of supplier knowledge integration on product innovation, we suggest scholars consider the effects of knowledge obtained from suppliers on both new product development and supply chain processes.

Third, this study empirically compares the joint effects of intellectual capital, supplier knowledge integration, and supply chain adaptability on product innovation performance in China and India. The majority of empirical studies on product innovation in emerging markets focus on China (Gao et al., 2015; Jean et al., 2014; Wang et al., 2011). This study is one of the first attempts to generalize and compare the findings in two important emerging markets. In this way, the results enhance current understandings on knowledge management and product innovation in India and the impacts of economic and institutional environments on supply chain management and new product development. We find that the economic development path and institutional environment moderate the effects of intellectual capital and supplier knowledge integration on product innovation performance. Therefore, we suggest scholars consider the influences of a country's special economic and institutional environments when exploring the effects of knowledge and supply chain management on new product development.

\subsection{Managerial Implications}


This study also provides guidelines for managers on how to develop new products using existing knowledge and supply chain management. First, manufacturers can improve product innovation performance by developing intellectual capital and integrating knowledge acquired from suppliers. In particular, manufacturers could implement training programs and job rotation to enhance employees' knowledge and skills. Manuals and standard operating procedures could be designed to formalize knowledge management and product development processes. Organizational procedures and rules could be created and regularly adjusted to guide cross-functional collaboration in new product development. Information systems and databases could also be used to keep knowledge automatically and systematically, and to facilitate the retrieval and implementation of knowledge in product innovation and supply chain management. In addition, lateral communication channels could be built for employees in different departments to share information and interact with each other. We suggest managers organize formal and informal social events, such as workshop, seminars, and parties, for employees to build and maintain personal relationships. Moreover, manufacturers could invest in operational processes and information technologies that enable them to obtain technical know-how on new product and process development from suppliers. For example, network-based information systems could be developed to allow real-time information sharing with suppliers. Cross-boundary teams could be formed to involve suppliers in new product development. This is especially important for Indian manufacturers because supplier knowledge integration mediates intellectual capital's effects on product innovation performance in India.

Second, we suggest manufacturers invest in improving supply chain adaptability when learning from suppliers for product innovation. Manufacturers could acquire 
knowledge about supply chain processes, such as inventory management, delivery scheduling, and process technologies, from suppliers. They could develop procedures and processes to apply the knowledge to solve supply chain problems and reengineer supply chains according to market changes. In this way, manufacturers are able to reap the full benefits of supplier knowledge integration on product innovation. This is especially important for Chinese manufacturers because supplier knowledge integration only enhances product innovation through supply chain adaptability in China.

Third, we find that the environmental conditions of a country moderate the impacts of intellectual capital and supplier knowledge integration on product innovation performance. Hence, we suggest managers analyse the institutional environment of a country and adjust the focus of supply chain learning accordingly. In particular, in a country that lacks market-supporting political and legal institutions, manufacturers could focus on acquiring the knowledge that can improve supply chain adaptability, such as process improvement suggestions and delivery scheduling, from suppliers. If a country has a good enough institutional environment, manufacturers could source the knowledge that can be directly applied into new product development, such as new product ideas and new applications of existing components and materials, and that can improve supply chain adaptability at the same time.

\subsection{Limitations and Future Research Directions}

Although this study makes significant theoretical and practical contributions, it has limitations that open avenues for future studies. First, a manufacturer can learn from different external partners, such as suppliers, customers, universities, and competitors, who can bring different kinds of knowledge (Un et al., 2010; Zhang et al., 2015). Future studies could explore the joint effects of the knowledge acquired from 
different partners and intellectual capital on product innovation performance. Second, we conduct this study in China and India. Manufacturers in other emerging markets (e.g., Russia and Brazil) or developed economies (e.g., North America and West Europe) face different economic and institutional environments compared to Chinese and Indian manufacturers. Investigating how intellectual capital and supply chain learning affect product innovation performance in other countries and comparing the results with this study would be an interesting research topic. Third, the survey has relatively low response rates, which is a limitation of this study.

\section{References}

Altenburg, T., Schmitz, H. and Stamm, A. 2008. Breakthrough? China's and India's transition from production to innovation. World Development 36(2), 325-344.

Atuahene-Gima, K. 2005. Resolving the capability-rigidity paradox in new product innovation. Journal of Marketing 69(4), 61-83.

Blome, C., Schoenherr, T. and Rexhausen, D. 2013. Antecedents and enablers of supply chain agility and its effect on performance: A dynamic capabilities perspective. International Journal of Production Research 51(4), 1295-1318.

Boeker, W. 1989. Strategic change: The effects of founding and history. Academy of Management Journal 32(3), 489-515.

Braunscheidel, M.J. and Suresh, N.C. 2009. The organizational antecedents of a firm's supply chain agility for risk mitigation and response. Journal of Operations Management 27(2), 119-140.

Breznitz, D. and Murphree, M. 2011. Run of the red queen: Government, innovation, globalization, and economic growth in China. New Haven: Yale University Press. Bruche, G. 2009. The emergence of China and India as new competitors in MNCs' 
innovation network. Competition \& Change 13(3), 267-288.

Chandy, R.K. and Tellis, G.J. 1998. Organizing for radical product innovation: The overlooked role of willingness to cannibalize. Journal of Marketing Research 34(4), 474-487.

Cheung, G.W. and Rensvold, R.B. 1999. Testing factorial variance across groups: A reconceptualization and proposed new method. Journal of Management 25(1), 1-27.

Cohen, W.M. and Levinthal, D.A. 1990. Absorptive capacity: A new perspective on learning and innovation. Administrative Science Quarterly 35(1), 128-152.

Cousins, P.D., Lawson, B., Petersen, K.J. and Handfield, R.B. 2011. Breakthrough scanning, supplier knowledge exchange, and new product development performance. Journal of Product Innovation Management 28(6), 930-942.

DiMaggio, P. J. and Powell, W. W. 1983. The iron cage revisited: Institutional isomorphism and collective rationality in organizational fields. American Sociological Review 48(2), 147-160.

Engelhardt-Nowitzki, C. 2012. Improving value chain flexibility and adaptability in build-to-order environments. International Journal of Physical Distribution \& Logistics Management 42(4), 318-337.

Ernst, H., Kahle, H.N., Dubiel, A., Prabhu, J. and Subrmaniam, M. 2015. The antecedents and consequences of affordable value innovations for emerging markets. Journal of Product Innovation Management 32(1), 65-79.

Fan, P. 2011. Innovation capacity and economic development: China and India. Economic Change and Restructuring 44(1/2), 49-73.

Fornell, C. and Larcker, D.F. 1981. Evaluating structural equation models with unobservable variables and measurement errors. Journal of Marketing Research 18(1), $39-50$. 
Gao, G.Y., Xie, E. and Zhou, K.Z. 2015. How does technological diversity in supplier network drive buyer innovation? Relational process and contingencies. Journal of Operations Management 36, 165-177.

Grant, R. M. 1996. Toward a knowledge-based theory of the firm. Strategic Management Journal 17(S1), 109-122.

Hsu, I. and Sabherwal, R. 2012. Relationship between intellectual capital and knowledge management: An empirical investigation. Decision Sciences 43(3), 489524.

Hsu, L. and Wang, C. 2012. Clarifying the effect of intellectual capital on performance: The mediating role of dynamic capability. British Journal of Management 23(2), 179-205.

Hu, L. and Bentler, P.M. 1999. Cutoff criteria for fit indices in covariance structure analysis: Conventional criteria versus new alternatives. Structural Equation Modelling 6(1), 1-55.

Hult, G.T.M., Ketchen Jr., D.J. and Slater, S.F. 2004. Information processing, knowledge development, and strategic supply chain performance. Academy of Management Journal 47(2), 241-253.

Hult, G.T.M., Ketchen Jr., D. J., Cavusgil, S. T. and Calantone, R.J. 2006. Knowledge as a strategic resource in supply chains. Journal of Operations Management 24 (5), 458-475.

Jean, R., Sinkovics, R.R. and Hiebaum, T.P. 2014. The effects of supplier involvement and knowledge protection on product innovation in customer-supplier relationships: A study of global automotive suppliers in China. Journal of Product Innovation Management 31(1), 98-113.

Kogut, B., and Zander, U. 1992. Knowledge of the firm, combinative capabilities, and 
the replication of technology. Organization Science 3(3), 383-397.

Lee, H.L. 2004. The triple-A supply chain. Harvard Business Review 83(10), 102-112.

Lee, J.Y., Swink, M. and Pandejpong, T. 2011. The role of worker expertise, information sharing quality, and psychological safety in manufacturing process innovation: An intellectual capital perspective. Production and Operations Management 20(4), 556-570.

Lindell, M.K. and Whitney, D.J. 2001. Accounting for common method variance in cross-sectional research designs. Journal of Applied Psychology 86(1), 114-121.

Malhotra, M.K., Singhal, C., Shang, G., and Ployhart, R.E. 2014. A critical evaluation of alternative methods and paradigms for conducting mediation analysis in operations management research. Journal of Operations Management 32(4), 127-137.

Marquis, C. and Tilcsik, A. 2013. Imprinting: Toward a multilevel theory. The Academy of Management Annals 7(1), 195-245.

Menor, L.J., Kristal, M.M. and Rosenzweig, E.D. 2007. Examining the influence of intellectual capital on capabilities and performance. Manufacturing \& Service Operations Management 9(4), 559-578.

Nahapiet, J. and Ghoshal, S. 1998. Social capital, intellectual capital, and the organizational advantage. Academy of Management Review 23(2), 242-266.

Parayil, G. and D'Costa, A.P. 2009. The new Asian innovation dynamics: China and India perspective. In: Technology, globalisation and development. England: Palgrave Macmillan.

Peng, M. W., Wang, D. and Jiang, Y. 2008. An institution-based view of international business strategy: A focus on emerging economies. Journal of International Business Studies 39(5), 920-936.

Petersen, K.J., Handfield, R.B. and Ragatz, G.L. 2003. A model of supplier 
integration into new product development. Journal of Product Innovation Management 20(4), 284-299.

Podsakoff, P.M., MacKenzie, S.B., Lee, J.Y. and Podsakoff, N.P. 2003. Common method biases in behavioural research: A critical review of the literature and recommended remedies. Journal of Applied Psychology 88(5), 879-903.

Prahalad, C.K. and Mashelkar, R.A. 2010. Innovation's holy grail. Harvard Business Review 88(7/8), 132-141.

Radjou, N., Prabhu, J. and Ahuja, S. 2012. Jugaad innovation: Think frugal, be flexible, generate breakthrough growth. San Francisco: Jossey-Bass.

Rajagopalan, N. and Zhang, Y. 2008. Corporate governance reforms in China and India: Challenges and opportunities. Business Horizons 51(51), 55-64.

Rungtusanatham, M., Ng, C.H., Zhao, X. and Lee, T.S. 2008. Pooling data across transparently different groups of key informants: Measurement equivalence and survey research. Decision Sciences 39(1), 115-145.

Saran, A. and Guo, C. 2005. Competing in the global marketplace: The case of India and China. Business Horizons 48(2), 135-142.

Simsek, Z., Fox, B. and Heavey, C. 2015. "What's past is prologue": A framework, review, and future directions for organizational research on imprinting. Journal of Management 41(1), 288-317.

Song, X.M., van Der Bij, H. and Weggeman, M. 2005. Determinants of the level of knowledge application: A knowledge-based and information-processing perspective. Journal of Product Innovation Management 22(5), 430-444.

Subramaniam, M. and Youndt, M.A. 2005. The influence of intellectual capital on the types of innovative capabilities. Academy of Management Journal 48(3), 450-463.

Swafford, P.M., Ghosh, S. and Murthy, N. 2006. The antecedents of supply chain 
agility of a firm: Scale development and model testing. Journal of Operations Management 24(2), 170-188.

Szulanski, G. 1996. Exploring internal stickiness: Impediments to the transfer of best practice within the firm. Strategic Management Journal 17(S1), 27-43.

Szulanski, G. 2000. The process of knowledge transfer: A diachronic analysis of stickiness. Organizational Behaviour and Human Decision Processes 82(1), 9-27.

Tavani, S.N., Sharifi, H. and Ismail, H.S. 2013. A study of contingency relationships between supplier involvement, absorptive capacity and agile product innovation. International Journal of Operations \& Production Management 34(1), 65-92.

Un, C.A., Cuervo-Cazurra, A. and Asakawa, K. 2010. R\&D collaborations and product innovation. Journal of Product Innovation Management 27(5), 673-689.

Wang, L., Yeung, J.H.Y. and Zhang, M. 2011. The impact of trust and contract on innovation performance: The moderating role of environmental uncertainty. International Journal of Production Economics 134(1), 114-122.

Youndt, M.A., Subramaniam, M. and Snell, S.A. 2004. Intellectual capital profiles: An examination of investments and returns. Journal of Management Studies 41(2), $335-361$

Zhang, M., Zhao, X., Lyles, M. and Guo, H. 2015. Absorptive capacity and mass customization capability. International Journal of Operations \& Production Management 39(5), 1275-1294.

Zhang, M., Zhao, X. and Qi, Y. 2014. The effects of organizational flatness, coordination, and product modularity on mass customization capability. International Journal of Production Economics 158, 145-155.

Zhou, K.Z. and Poppo, L. 2010. Exchange hazards, relational reliability, and contracts in China: The contingent role of legal enforceability. Journal of International 
Business Studies 41(5), 861-881.

1

2

3

4

5

6

7

8

9

10

11

12

13

14

15

16

17

18

19

20

21

22

23

24

25

26

27

28

29

30

31

32

33

34

35

36

37

38

39

40

41

42

43

44

45

46

47

48

49

50

51

52

53

54

55

56

57

58

59

60 
Appendix Measurement items

\begin{tabular}{|c|c|c|}
\hline+1 & China & India \\
\hline \\
\hline Human capital & $\mathrm{AVE}=0.70, \mathrm{CR}=0.87, \mathrm{Alpha}=0.78$ & $\mathrm{AVE}=0.72, \mathrm{CR}=0.89, \mathrm{Alpha}=0.81$ \\
\hline 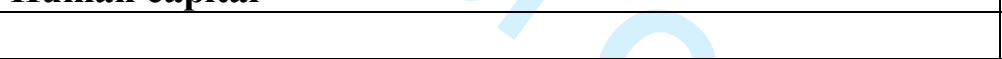 & .857 & .943 \\
\hline $\begin{array}{l}\text { Employees in the company are highly skilled in their } \\
\text { respective jobs. }\end{array}$ & .781 & .777 \\
\hline $\begin{array}{l}\text { Employees in the company are experts in their particular jobs } \\
\text { and functions. }\end{array}$ & .700 & .733 \\
\hline Our employees always develop new ideas and knowledge. & .729 & .776 \\
\hline Structural capital & $\mathrm{AVE}=0.71, \mathrm{CR}=0.88, \mathrm{Alpha}=0.79$ & $\mathrm{AVE}=0.65, \mathrm{CR}=0.85, \mathrm{Alpha}=0.73$ \\
\hline 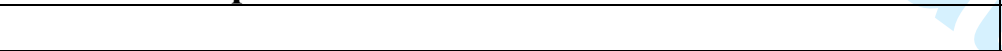 & .717 & .977 \\
\hline $\begin{array}{l}\text { Much of this company's knowledge is contained in manuals, } \\
\text { archives, or databases. }\end{array}$ & .765 & .652 \\
\hline $\begin{array}{l}\text { We usually follow the sequence of written procedures and } \\
\text { rules. }\end{array}$ & .707 & .686 \\
\hline $\begin{array}{l}\text { Our company embeds much of its knowledge and information } \\
\text { in structures, systems, and processes. }\end{array}$ & .779 & .744 \\
\hline Social capital & $\mathrm{AVE}=0.68, \mathrm{CR}=0.87, \mathrm{Alpha}=0.76$ & $\mathrm{AVE}=0.64, \mathrm{CR}=0.84, \mathrm{Alpha}=0.72$ \\
\hline & +8 & .853 \\
\hline $\begin{array}{l}\text { There are ample opportunities for informal conversations } \\
\text { among employees in the company. }\end{array}$ & .633 & .589 \\
\hline $\begin{array}{l}\text { Employees from different departments feel comfortable } \\
\text { calling each other when the need arises. }\end{array}$ & .825 & .720 \\
\hline People are quite accessible to each other in the company. & .726 & .747 \\
\hline Supplier knowledge integration & $\mathrm{AVE}=0.71, \mathrm{CR}=0.87, \mathrm{Alpha}=0.87$ & $\mathrm{AVE}=0.63, \mathrm{CR}=0.87, \mathrm{Alpha}=0.81$ \\
\hline $\begin{array}{l}\text { We are able to obtain a tremendous amount of technical } \\
\text { know-how from suppliers. }\end{array}$ & .820 & .803 \\
\hline
\end{tabular}




\begin{tabular}{|l|c|c|}
\hline $\begin{array}{l}\text { We rapidly respond to technological changes in our industry } \\
\text { by applying what we have learned from suppliers. }\end{array}$ & .807 & .708 \\
\hline $\begin{array}{l}\text { As soon as we acquire new knowledge from suppliers, we try } \\
\text { to find applications for it. }\end{array}$ & .778 & .659 \\
\hline $\begin{array}{l}\text { Suppliers' technological knowledge has enriched the basic } \\
\text { understanding of our innovation activities. }\end{array}$ & AVE=0.68, CR=0.89, Alpha=0.84 & AVE=0.68, CR=0.89, Alpha=0.84 \\
\hline Supply chain adaptability & .724 & .797 \\
\hline $\begin{array}{l}\text { Our supply chain partners can help us to quickly change } \\
\text { product designs. }\end{array}$ & & .835 \\
\hline We can quickly solve supply chain problems. & .861 & .825 \\
\hline Our supply chain can adapt to market changes easily. & .631 & .695 \\
\hline $\begin{array}{l}\text { We can quickly conduct engineering changes to adapt to } \\
\text { customer's needs. }\end{array}$ & AVE=0.72, CR=0.91, Alpha=0.87 & AVE=0.67, CR=0.89, Alpha=0.84 \\
\hline Product innovation performance & .660 & .760 \\
\hline Percentage of total sales stemming from new products. & .807 & .756 \\
\hline Number of new products. & .841 & .707 \\
\hline Speed of introducing new products. & .870 & .780 \\
\hline Frequency of new product introductions. & & \\
\hline
\end{tabular}

Note: AVE: average variance extracted; CR: composite reliability; Alpha: Cronbach's $\alpha$ 


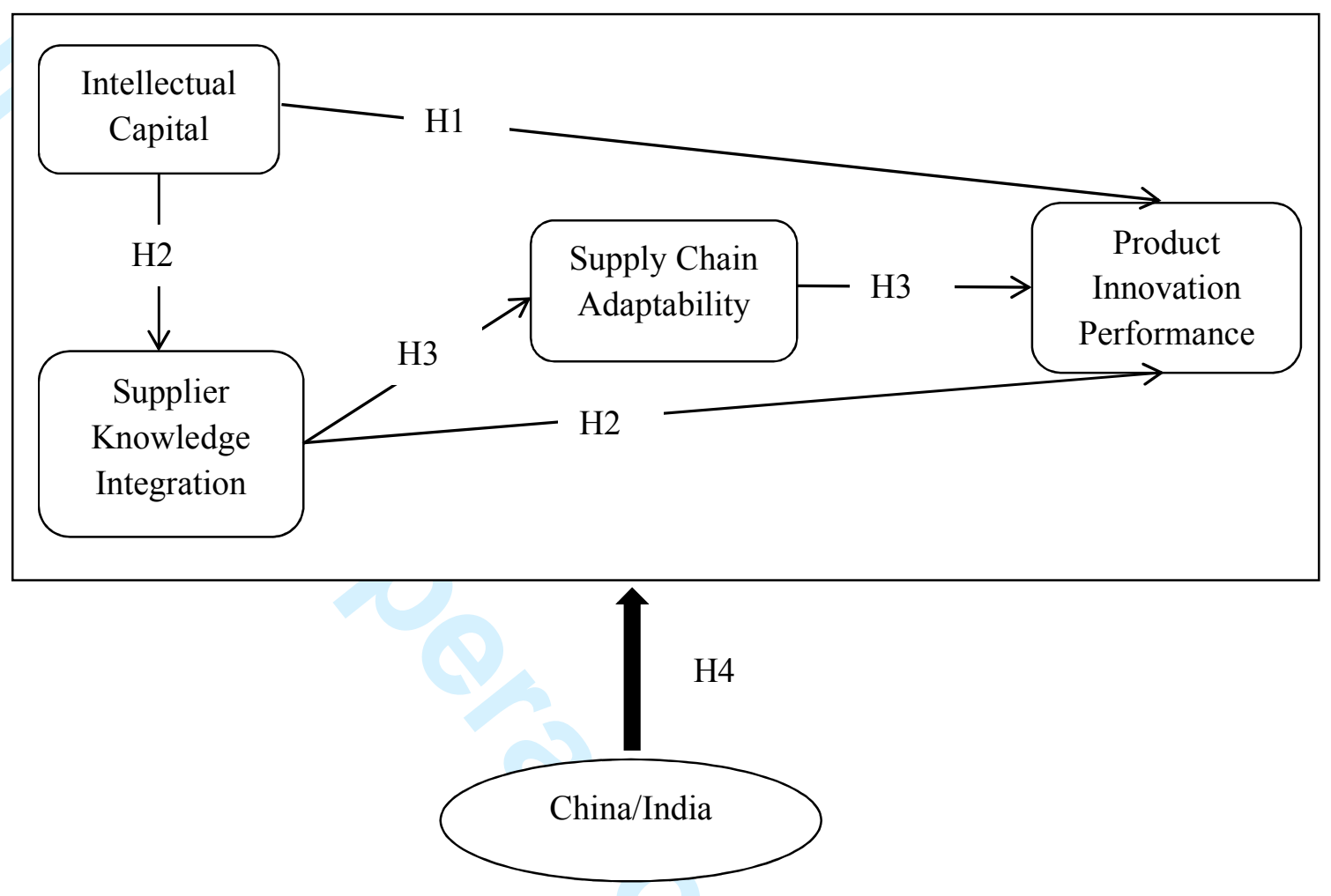

Figure 1. Conceptual framework 


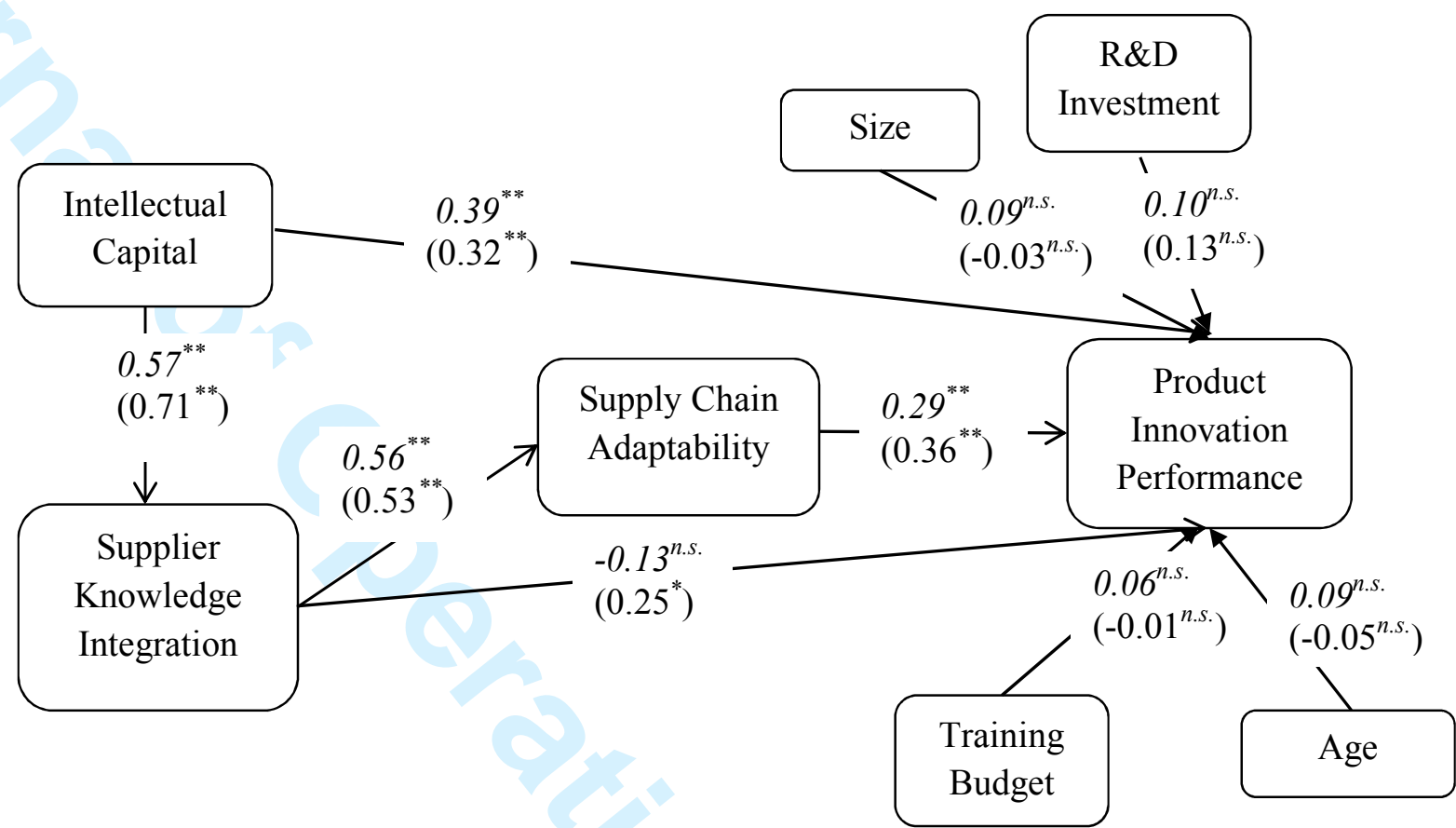

Note: $* * \mathrm{p}<0.01 ; * \mathrm{p}<0.05$; n.s.: not significant. The results of the Chinese sample are shown in italic font and those of the Indian sample are shown in parentheses.

Figure 2. Results of statistical analysis 
Table 1. Economic growth in China and India

\begin{tabular}{|c|c|c|c|c|c|c|}
\hline & \multicolumn{2}{|c|}{1990} & \multicolumn{2}{|c|}{2000} & \multicolumn{2}{|c|}{2005} \\
\hline & China & India & China & India & China & India \\
\hline $\begin{array}{l}\text { GDP (current US\$, } \\
\text { Billion) }\end{array}$ & 359 & 327 & 1205 & 477 & 2269 & 834 \\
\hline $\begin{array}{l}\text { GDP growth } \\
\text { (annual \%) }\end{array}$ & 3.93 & 5.53 & 8.43 & 3.84 & 11.35 & 9.28 \\
\hline $\begin{array}{c}\text { Foreign direct } \\
\text { investment, net } \\
\text { inflows (current US\$, } \\
\text { Billion) }\end{array}$ & 3.49 & 0.23 & 38 & 3.58 & 111 & 7 \\
\hline $\begin{array}{l}\text { Exports of goods and } \\
\text { services ( } \% \text { of GDP) }\end{array}$ & 15.90 & 6.93 & 20.68 & 12.77 & 33.70 & 19.28 \\
\hline $\begin{array}{c}\text { High-technology } \\
\text { exports (\% of } \\
\text { manufactured exports) }\end{array}$ & $\mathrm{n} / \mathrm{a}$ & 3.94 & 18.98 & 6.26 & 30.84 & 5.80 \\
\hline
\end{tabular}


Table 2. Firm profiles

\begin{tabular}{|c|c|c|}
\hline & China & India \\
\hline \multicolumn{3}{|l|}{ Annual sales (USD) } \\
\hline Less than 50 million & 62.3 & 78.0 \\
\hline 50 to 100 million & 17.0 & 10.5 \\
\hline 100 to 250 million & 12.0 & 4.5 \\
\hline More than 250 million & 8.7 & 7.0 \\
\hline \multicolumn{3}{|l|}{ Industry } \\
\hline Biology \& pharmaceuticals & 6.0 & 16.0 \\
\hline Computer \& telecommunication equipment & 11.3 & 6.5 \\
\hline Chemicals & 17.0 & 9.5 \\
\hline Medical equipment & 9.3 & 3.5 \\
\hline Electronics \& electrical equipment & 18.0 & 21.0 \\
\hline Industrial machinery & 16.3 & 27.5 \\
\hline Transportation equipment & 11.7 & 6.0 \\
\hline New materials & 10.3 & 4.0 \\
\hline \multicolumn{3}{|l|}{ Years of operation } \\
\hline Less than 10 years & 26.7 & 25.0 \\
\hline 11 to 20 years & 46.6 & 44.0 \\
\hline 21 to 30 years & 11.0 & 19.5 \\
\hline More than 30 years & 16.7 & 11.5 \\
\hline \multicolumn{3}{|l|}{ Number of employees } \\
\hline Less than 200 & 22.3 & 64.8 \\
\hline 201 to 500 & 41.7 & 16.6 \\
\hline 501 to 1000 & 17.3 & 9.1 \\
\hline More than 1000 & 18.7 & 9.5 \\
\hline \multicolumn{3}{|l|}{ R\&D investment (\% of annual sales) } \\
\hline Less than $0.5 \%$ & 12.3 & 24.0 \\
\hline $0.51 \%$ to $1.0 \%$ & 8.7 & 38.5 \\
\hline $1.1 \%$ to $2.0 \%$ & 15.0 & 13.5 \\
\hline 2.1 to $4.0 \%$ & 48.0 & 8.0 \\
\hline More than $4.0 \%$ & 16.0 & 16.0 \\
\hline \multicolumn{3}{|l|}{ Training budget ( $\%$ of annual sales) } \\
\hline Less than $1.0 \%$ & 68.3 & 27.0 \\
\hline $1.1 \%$ to $2.0 \%$ & 18.0 & 40.5 \\
\hline $2.1 \%$ to $4.0 \%$ & 13.7 & 19.5 \\
\hline More than $4.0 \%$ & 0.0 & 13.0 \\
\hline
\end{tabular}

Note: The numbers in the China and India columns are percentages of manufacturing firms. 
Table 3. Correlations, means, and standard deviations

\begin{tabular}{llllllll}
\hline & HC & StC & SoC & SKI & SCA & PIP \\
\hline China & Human capital (HC) & $\mathbf{0 . 8 4}$ & & & & & \\
& Structural capital (StC) & 0.44 & $\mathbf{0 . 8 4}$ & & & & \\
Social capital (SoC) & 0.51 & 0.45 & $\mathbf{0 . 8 2}$ & & & \\
Supplier knowledge integration & 0.33 & 0.31 & 0.38 & $\mathbf{0 . 8 4}$ & & \\
(SKI) & & & & & & \\
Supply chain adaptability (SCA) & 0.51 & 0.49 & 0.44 & 0.47 & $\mathbf{0 . 8 2}$ & \\
Product innovation performance & 0.48 & 0.25 & 0.27 & 0.19 & 0.41 & $\mathbf{0 . 8 5}$ \\
(PIP) & & & & & & \\
Mean & 4.99 & 5.71 & 5.69 & 5.25 & 5.32 & 4.65 \\
Standard deviation & 0.96 & 0.95 & 0.90 & 1.00 & 0.95 & 1.10 \\
Hndia & $\mathbf{0 . 8 5}$ & & & & & \\
& Structural capital & 0.70 & $\mathbf{0 . 8 1}$ & & & & \\
Social capital & 0.59 & 0.66 & $\mathbf{0 . 8 0}$ & & & \\
Supplier knowledge integration & 0.54 & 0.49 & 0.39 & $\mathbf{0 . 7 9}$ & & \\
Supply chain adaptability & 0.50 & 0.46 & 0.46 & 0.39 & $\mathbf{0 . 8 2}$ & \\
Product innovation performance & 0.60 & 0.50 & 0.45 & 0.53 & 0.58 & $\mathbf{0 . 8 2}$ \\
Mean & 5.76 & 5.56 & 5.70 & 5.58 & 5.39 & 5.45 \\
Standard deviation & 0.83 & 0.87 & 0.76 & 0.86 & 0.83 & 0.80 \\
\hline
\end{tabular}

Note: The square root of average variance extracted (AVE) is shown on the diagonal of each matrix in bold. Inter-construct correlation is shown off the diagonal of each matrix. All of the correlations are significant at the 0.01 level.

Table 4. Results of cross-country comparison

\begin{tabular}{lccc}
\hline \multicolumn{1}{c}{ Equal Paths } & $\Delta C F I$ & $\Delta T L I$ & $\Delta \chi^{2}$ \\
\hline Intellectual capital $\rightarrow$ Product innovation performance & 0.000 & 0.000 & $\mathbf{3 . 1 8}^{+}$ \\
Intellectual capital $\rightarrow$ Supplier knowledge integration & 0.000 & 0.000 & 0.14 \\
Supplier knowledge integration $\rightarrow$ Supply chain adaptability & 0.000 & 0.000 & 0.01 \\
Supplier knowledge integration $\rightarrow$ Product innovation & -0.002 & -0.002 & $\mathbf{1 0 . 7 3}^{*}$ \\
performance & & & \\
Supply chain adaptability $\rightarrow$ Product innovation performance & 0.000 & 0.00 & 0.05 \\
\hline Note: ${ }^{*} \mathrm{p}<0.05 ;{ }^{+} \mathrm{p}<0.1$ & & &
\end{tabular}

